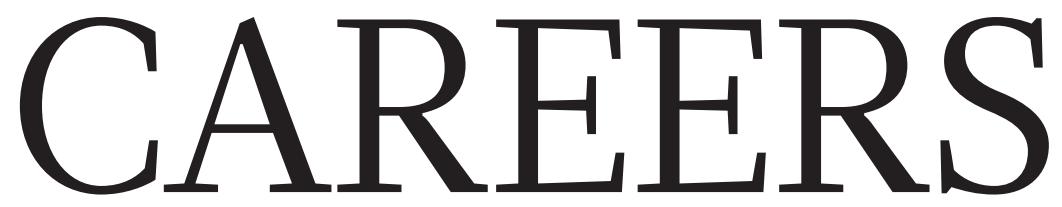

POSTDOC PENALTY EX-postdocs earn less than non-postdocs outside academia $\mathbf{p . 2 6 3}$
IN DEMAND Report says United Kingdom to seek workers with STEM skills $\mathbf{p . 2 6 3}$
NATUREJOBS For the latest career

listings and advice www.naturejobs.com

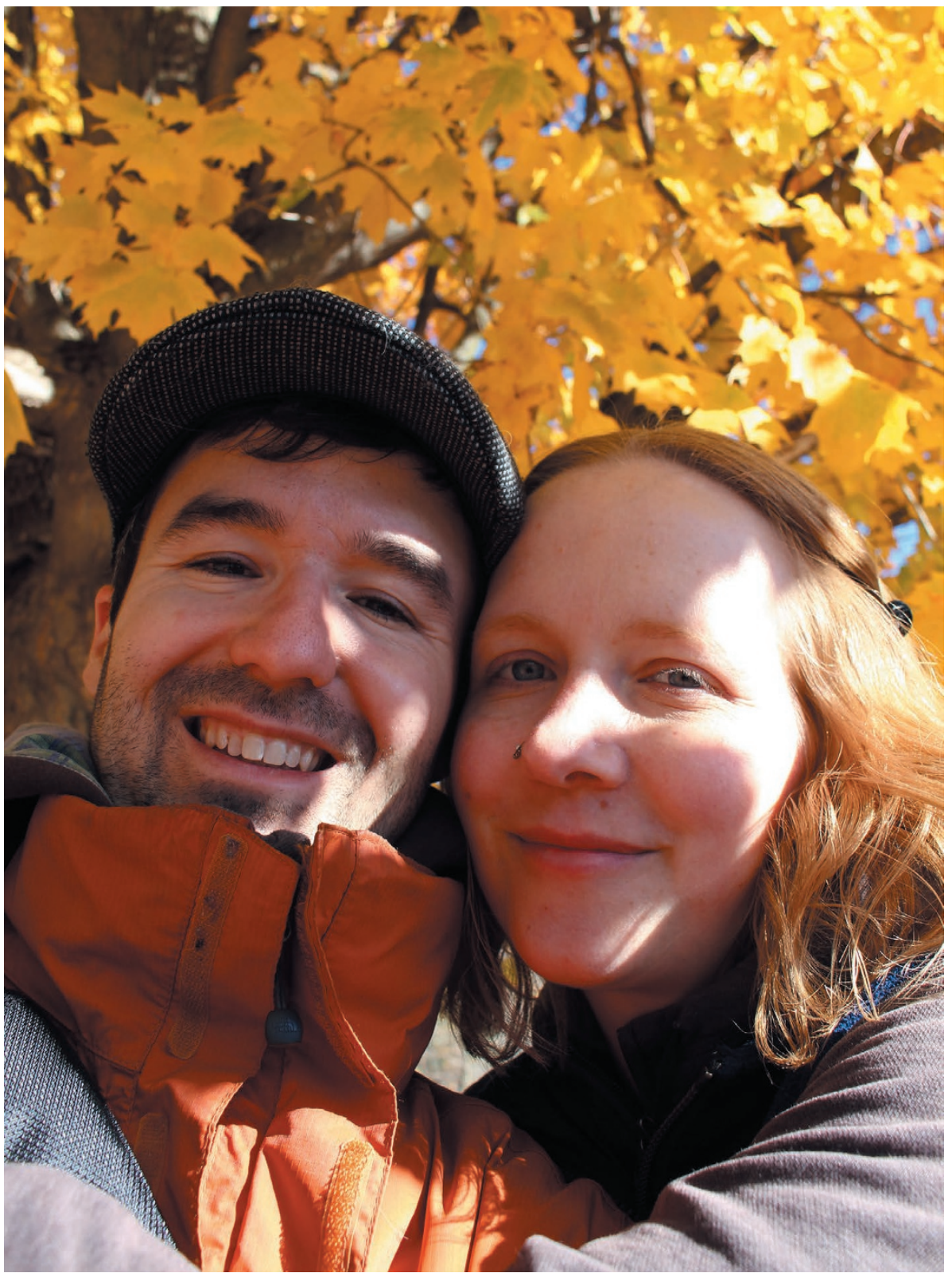

Eric Chevalier and Erin Zimmerman met at the Plant Biology Research Institute in Montreal, Canada.

\title{
Sweethearts in science
}

When couples are colleagues, work-life balance is key.

$\mathrm{E}$ very few days, Alan Flint plucks a gardenia from outside the building where his wife, Lorraine, works in Sacramento, California. He replaces the fading flower on her desk and refills the glass with fresh water.

It's an easy romantic gesture, given that Alan's office is right down the hall. The Flints are both research hydrologists with the US Geological Survey California Water Science Center. It's the farthest apart their offices have been for years: they met during secondary school, married in 1975 and have been next door to each other throughout much of their careers in soil science.

There are many couples in science similar to the Flints - and this Valentine's Day, Alan might not be the only one delivering flowers to an office down the hall. For researcher couples, obvious advantages can range from reviewing each other's writing to carpooling. Yet there are potential downsides, from navigating the challenge of finding and holding dual jobs to concerns about potential or existing conflicts of interest - such as when one partner sits on a promotions committee that discusses the other - or what might happen if the romance collapses (see 'Science soldiers on').

According to a 2008 report by the Clayman Institute for Gender Research at Stanford University in California, which collected data on around 9,000 faculty members at 13 universities, $36 \%$ of US faculty members were part of an academic couple ${ }^{1}$. Of those, $38 \%$ worked in the same department as their partner. Professors in the natural sciences were particularly likely to work in similar fields or the same department: $83 \%$ of female scientists and $54 \%$ of male scientists in academic couples had another scientist as a partner.

A report released by the US National Science Foundation in 2015 found that $73 \%$ of scientists were married, and $24 \%$ of their employed spouses worked in engineering, computing, mathematics or the natural sciences 2 . "I know so many of my colleagues here who are married to another scientist on this campus," says Alexis Templeton, a geologist at the University of Colorado Boulder. In Europe, too, it's common for scientists to marry another scientist, says Phil Stanier, a geneticist at University College London - although it's less common for them to work as closely as he does with his wife, geneticist Gudrun Moore, with whom he's co-authored dozens of papers.

A 2016 report by the European Commission (EC) similarly found that $72 \%$ of surveyed 
- researchers were in a relationship, and, of those, $54 \%$ were partnered with a person who was also pursuing a demanding career (although not necessarily in science) $^{3}$.

\section{'TIL DATA DO US PART}

Some couples deliberately keep their careers separate and don't talk much shop on evenings and weekends. Others, such as the Flints, are driven by a shared goal, and seamlessly integrate their work and home lives. Ultimately, navigating a relationship and career as a member of a scientist couple requires mutual respect, effort to carve out two distinct niches and a hearty dose of cooperation.

Married wildlife biologists Paula MacKay and Robert Long laugh at the idea of setting boundaries between personal and professional activities. The pair was once halfway up a mountain, carrying odorous bear-scent lures, when MacKay realized that it was their wedding anniversary. Long, a senior conservation scientist at Woodland Park Zoo in Seattle, Washington, and MacKay, a contract field biologist whose clients include the zoo, had been so involved in planning their trip that they had both forgotten the date. "I feel like I'm always out there with my best friend," MacKay says. "When we approach a remote camera site or a place where we had set out a station before, it's really exciting to be there with Rob."

That shared joy is one of the myriad benefits of dual employment as researchers. Those might be as simple as grabbing lunch for one's partner on a busy day, as Frances Rena Bahjat and Keith Bahjat of Bristol-Myers Squibb in Redwood City, California, frequently do for each other. Frances Rena is senior director of in vivo studies and Keith directs cellular immunology at the company. To keep up with the literature, they also play a 'Who can find the best papers?' game each week, and they recommend potential collaborators to each other. "The two of us have much more reach than a single scientist, that's for sure," says Frances Rena.

One partner's enthusiasm for science, or for a particular field, can be contagious. Frances Rena says that she probably wouldn't have become a scientist if she hadn't met her husband (and now, colleague) when both were undergraduates. She didn't understand how science could be a career until she met Keith, whose father was a geophysicist. Similarly, Alan Flint started his career in soil science before Lorraine followed, and their couple status has even helped in a job search. As Alan was finishing his $\mathrm{PhD}$ and Lorraine her master's, their adviser heard about a lab that was looking for two soil scientists - one at the $\mathrm{PhD}$ level and one at the master's level. They got the jobs.

This situation is not uncommon: in the Clayman Institute report ${ }^{1}, 10 \%$ of faculty members were hired as a couple, and as of 2008, that rate was on the rise. Usually, one partner was hired first and negotiated for the other. Men were more often the first hire at that time, and the second hire was more likely to be in a junior faculty position.

For many couples, such as geneticists Moore and Stanier of University College London, working together enhances both the relationship and research. The pair met during the 1980 s at St Mary's Hospital in London. After a series of lecturer and postdoc positions, both worked at Imperial College London for a time, sharing equipment, working on each other's grants and co-authoring papers. They tried working apart, but didn't like it. "We're stronger together," says Moore. For example, the pair was able to productively combine Moore's

\section{WHEN LOVE GOES AWAY}

\section{Science soldiers on}

Kay Davies married Stephen Davies in 1973, and in 1983, they began collaborating on a treatment for muscular dystrophy. Both work at the University of Oxford, UK, where Kay directs the Medical Research Council's functional-genomics unit.

The pair split in 2000, but their research continues unabated. Stephen's chemistry group provides the small molecules that Kay's lab screens for efficacy. Three years after the divorce, they co-founded Summit Therapeutics in Abingdon, UK. Only Stephen serves on the board, because the two worried that their personal history might make others uncomfortable, says Kay.

May-Britt Moser and Edvard Moser, who co-direct the Kavli Institute for Systems Neuroscience and the Centre for Neural Computation at the Norwegian University of Science and Technology in Trondheim, underwent a similar journey. They married in 1985, shared the Nobel Prize in Physiology or Medicine in 2014 and divorced in 2016. Their scientific collaboration continues, because they still share the same "vision, values and ambitions", says May-Britt. Some couples with common interests may be able to work together after a break-up; others may prefer to work independently, adds Edvard.

"If you're both passionate about [the research], you can work it out," says Kay Davies. Certainly, it was difficult to tell colleagues and lab members about the break-up, she says, but she and Stephen were fully committed to their professional goals.

"You just have to rise above it," she advises. "If you're very focused on where you both want to get to, it's the secret of success." A.D.

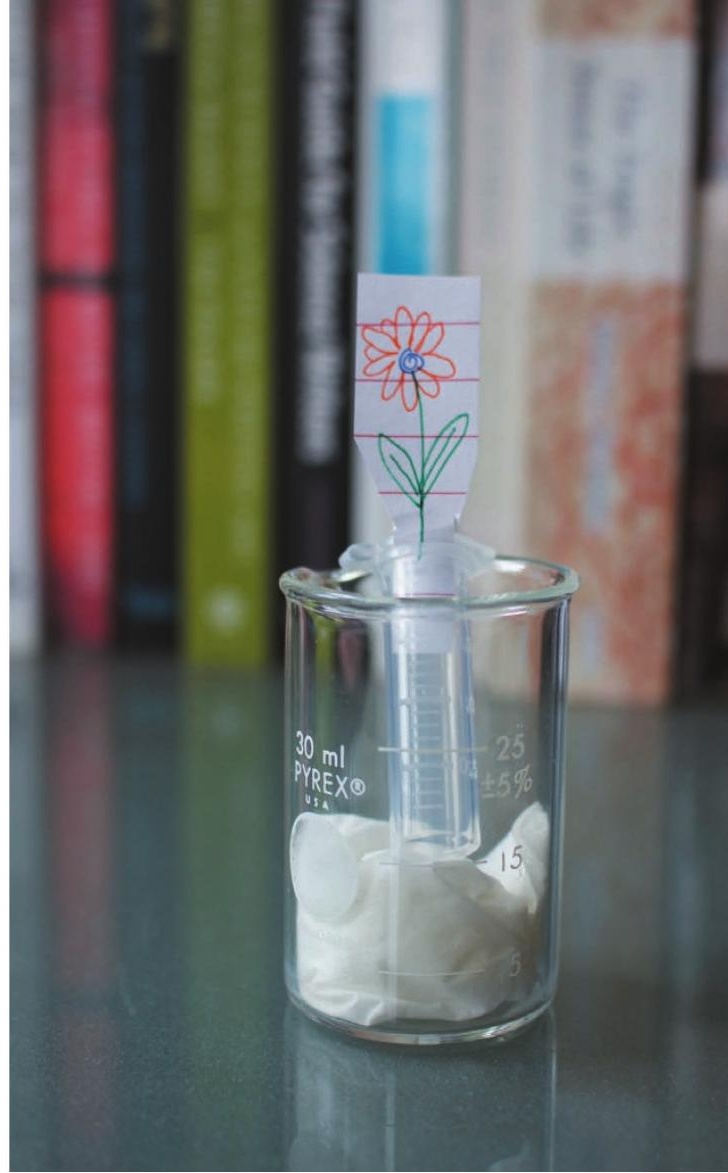

Love blossoms a little differently in the lab.

background in protein chemistry and Stanier's in molecular cloning when they searched for a gene associated with X-linked cleft palate.

Working together and being able to continue the discussion at home is a big advantage for the research, agrees Shin-ichi Horike, a geneticist at Kanazawa University in Japan whose wife, Makiko Meguro, works in his lab. When a grant deadline is coming up, science is a major item on the conversation agenda at their house, albeit after the children have gone to bed. They discuss results of their experiments on those evenings.

\section{KEEPING IT CIVIL}

For partners who collaborate closely, division of expertise is crucial. "You have to develop complementary skills so that you're not in competition with each other," says Lorraine Flint. And it's important, for the relationship, to take a bit of time away from science, say the Flints. They've set aside a daily cocktail hour.

Ethologists Rick D'Eath and Susan Jarvis of Scotland's Rural College in Easter Bush, UK, don't work on exactly the same science, but they use each other as a sounding board to practise major presentations. Both can approach other colleagues for feedback, but are fully - even brutally - honest with each other. Jarvis feels perfectly comfortable telling her husband that his points are "a bit rubbish".

Whether scientist couples work closely or just share an employer, many say that they appreciate the ability to provide mutual support through tough times at work. Allison Mattheis, an educational researcher at California State University (Cal State) in Los Angeles, met her partner, Valerie Wong, when they were both 
at the University of Minnesota - Mattheis at the Minneapolis campus and Wong in St Paul. Now, Wong is an adjunct faculty member at Cal State. "You get frustrated by all the same bureaucratic hurdles of the institution," says Mattheis. Who better to commiserate with over Mattheis's struggles to add her partner to her health insurance than Wong?

The two talk about how best to design lessons, address students' misconceptions or advise students. Wong also refers biology students with an interest in teaching to Mattheis. The two have started a project to connect secondary-school teachers with university instructors to improve early science education.

These relationships are of value to scientists still in training, too. Erin Zimmerman of London, Canada, misses this kind of connection now that she and her husband, Eric Chevalier, no longer work in science. Although they met as graduate students in the Plant Biology Research Institute at the University of Montreal, Canada, she's now a freelance science writer; he, an optometrist at Old South Optometry in London. When they began dating, it was easy to keep in contact. Chevalier once placed a picture of a hand-drawn flower into a beaker on Zimmerman's desk, because he knew she hated how real cut flowers die. They co-authored a review, and related to each other's dealings with academic culture, funding woes and other frustrations. "It was nice being able to have someone at home who really understood that," says Zimmerman. "Now," she jokes, "we bore each other."

There are potential pitfalls to such a relationship. For one, those determined to work together might limit their options.
"Your relationship is living in a fishbowl." husband, Robert Harron, as an academic mentor when she was applying for grant support. "If we weren't related, I would be the natural choice," says her husband, a maths faculty member at the university, but he knew that any reports or letters of recommendation that he might write about her would be suspect. Nonetheless, they contribute to each other's work, reading and editing their writing. Piper excels at bits that sell the projects, and Robert is good at converting text into more maths-oriented language.

Sharing a last name might also raise eyebrows, adds biochemist Edith Sim of Oxford, UK, who met her husband, Bob Sim, when they were undergraduate laboratory partners. They worked in each other's labs at times. Once, a grant application that she had submitted came back with the comment, "Was this hers or was this her husband's?" From then on, she left her husband's name off any papers that she produced.

By contrast, colleagues of Moore and Stanier didn't always catch on that they were married. "We didn't hide it, but we didn't particularly flaunt it," explains Stanier. One visiting student spent a few months in Moore's lab while Stanier was a postdoc there, and thought the two were engaged in a scandalous affair. (His adviser set him straight.)

Another issue that couples may want to consider, points out Keith Bahjat, is that when a couple works for the same employer, both members depend on that employer for their wages. That's a particular concern in industry, he says, where companies might impose layoffs at any time. D'Eath and Jarvis had the same concern, which they've mitigated in part by Jarvis taking a second position as director of a master's programme at the University of Edinburgh, UK, in addition to her work at Scotland's Rural College. Now they feel safer, because it's unlikely that both institutions would falter at the same time.

Despite these challenges, scientist couples know that they enjoy significant good fortune. "Finding a situation where you both have great opportunity is really rare," says Frances Rena Bahjat.

Amber Dance is a freelance writer in Los Angeles, California.

1. Michelle R. Clayman Institute for Gender Research. Dual-Career Academic Couples (Stanford Univ., 2008).

2. US National Science Foundation. Women, Minorities, and Persons with Disabilities (NSF, 2015).

3. European Commission. Research Careers in Europe (EC, 2016). Michigan in Ann Arbor. Both joined the lab as employees once they graduated, and, for a time, Grosskopf was Marion's supervisor. But when romance blossomed, he warned his boss, who changed Marion's supervisor.

Similarly, mathematician Piper Harron, a temporary faculty member at the University of Hawaii at Manoa, avoided selecting her

\section{CORRECTION}

The Careers feature 'Code alert' (Nature 541, 563-565; 2017) gave the wrong affiliation for Andrew Durso. He is at Utah State University in Logan.

\section{SALARY}

\section{Postdoc penalty}

Completing a US postdoctoral-research stint in biomedical sciences leads to thousands of dollars in lost earnings, a study finds (S. Kahn and D. K. Ginther Nature Biotechnol. 35, 90-94; 2017). Researchers tracked the careers of 10,402 people who received a biomedical $\mathrm{PhD}$ in the United States between 1980 and 2010. They found that, ten years after graduating, those who had done a postdoc earned an average of US\$12,002 (11\%) less than those who had not. "Ex-postdocs pay an earnings penalty for up to 15 years," the study says, noting that the penalty could discourage top-level candidates from pursuing careers in biomedical science. Over that period, ex-postdocs earned $\$ 128,297$ (17\%) less in non-tenure-track academic research; $\$ 239,970$ (21\%) less in industry; and \$161,142 (17\%) less in government and non-profit positions. The study found that non-postdocs were as likely as ex-postdocs to work in government or non-profit positions, suggesting that hirers and managers in those sectors do not seek candidates who have completed postdoctoral research. Employers outside academia place no financial value on skills or training acquired through a postdoc position, the study says.

\section{JOBS}

\section{Seeking STEM skills}

A report from a UK think tank predicts that more than 100,000 new jobs and 600,000 vacancies in science, technology, engineering and maths (STEM) will be created in the United Kingdom between now and 2023 (go.nature.com $/ 2 \mathrm{kmhxgk}$ ). Jobs of the Future, produced by the Social Market Foundation in London, used government data to analyse growth trends in Britain's STEM industries. Fields that will produce the most new jobs include scientific research and development; computing services, particularly programming and coding; information services; and telecommunications, the report predicts. Although demand for conventional STEM jobs will remain high, the report predicts that candidates with technology and research-based skills will be sought for positions in consultancy, in legal, accounting and financial services and in management. The report found that women in STEM positions in 2016 totalled just over 460,000 and accounted for $19 \%$ of jobs in the combined sectors. With gender parity the total would be 1.2 million, the report says. It calls for more women to study the sciences in school and at university. 